\title{
INSTALASI SISTEM PEMANTAUAN KUALITAS AIR ONLINE BERBASIS GSM DI SUNGAI CILIWUNG SEGMEN ISTIQLAL
}

\author{
GSM Based Online Water Quality Monitoring System Installation At Ciliwung River Part Istiqlal Mosque \\ Oleh: \\ Heru Dwi Wahjono dan Galih Setiaji \\ Pusat Teknologi Lingkungan, BPPT
}

\begin{abstract}
Abstrak
Sungai Ciliwung adalah salah satu sungai yang melewati wilayah administratif Provinsi DKI Jakarta. sungai ciliwung telah dikategorikan sebagai sungai yang tercemar berat. Untuk mengendalikan pencemaran maka perlu dilakukan pemantauan kualitas air sungai. Pemantauan kualitas sebaiknya dilakukan secara terus-menerus setiap saat. Untuk itu maka dilakukan ujicoba pemantauan kualitas air yang dipasang pada area Sungai Ciliwung bagian Masjid Istiqlal. Sistem yang diujicobakan adalah sistem pemantauan kualitas air online dan realtime yang berbasis GSM. Dalam tulisan ini membahas mengenai proses instalasi, hasil pemantauan, modifikasi struktur pelindung sensor dan kendala yang dihadapi. Dari kegiatan ini menghasilkan beberapa kesimpulan mengenai: bentuk bangunan pelindung yang cocok, jangka waktu kalibrasi sensor, kendala yang dihadapi, kehandalan sistem, dan upaya untuk meningkatkan kinerja sistem.
\end{abstract}

Kata Kunci : Bangunan pelindung, periode kalibrasi, hasil pemantauan, kualitas air, realtime.

\begin{abstract}
Ciliwung River is one of the rivers that pass through the administrative area of Jakarta. Ciliwung river has been categorized as a heavy polluted river. The water quality monitoring needs to be installed to control river pollution. The Water quality monitoring should be performed at any time continuously. For that reason, The trial water quality monitoring that placed in the area of Ciliwung part Istiqlal Mosque has been installed. The installed system that based on GSM network is an online and realtime water quality monitoring. In this paper discusses the process of installation, monitoring results, modification of protective structure and the problems were encountered. From this activity bring out some conclusions about: shape of suitable protective building, sensor calibration period, the obstacles encountered, system reliability, and efforts to improve system performance.
\end{abstract}

Keywords: Protective building, calibration period, monitoring result, water quality, realtime.

\section{PENDAHULUAN}

\subsection{Latar Belakang}

Seiring bertambahnya penduduk di kota-kota besar maupun di wilayah daerah aliran sungai akan berdampak berupa pencemaran perairan sungai yang cukup besar. Sumber pencemar yang dihasilkan berasal dari buangan limbah domestik maupun limbah industri yang ada di daerah aliran sungai tersebut. Sungai yang semula berfungsi sebagai salah satu komponen siklus hidrologi kini telah beralih fungsi sebagai tempat pembuangan limbah. Ekosistem disekitar sungai yang seharusnya menjadi tempat berlangsungnya siklus hidup organisme kini telah menjadi bangunan tanggul dan jalan inspeksi. Saat ini dari 53 sungai di Indonesia, sebesar 73 persen di antaranya telah tercemar (Tempo.CO, 2015) . Demi menjaga keseimbangan ekosistem wilayah sungai tersebut, sudah saatnya dilakukan restorasi.

Saat ini pemerintah Indonesia sudah mulai memikirkan rencana untuk merestorasi sungai-sungai di kota-kota besar di indonesia. Salah satu pilot project restorasi sungai yang mulai dilakukan adalah restorasi di sungai Ciliwung segmen Istiqlal. Pilot project restorasi sungai ini merupakan hasil kerjasama antara Pemerintah Korea dengan Kementerian Lingkungan Hidup dan Kehutanan Republik Indonesia. Bentuk pilot project ini diantaranya: 1) sistem pengolahan air limbah untuk meminimalkan polutan yang masuk ke sungai Ciliwung segmen Istiqlal, 2) mengembalikan bentuk sungai Ciliwung di segmen Istiqlal menjadi 
bentuk yang mengedepankan fungsi ekohidrologi, 3) membuat pusat pendidikan lingkungan di lokasi tersebut (Kementerian Lingkungan Hidup, 2015).

Sungai Ciliwung adalah salah satu sungai yang melewati wilayah administratif Provinsi DKI Jakarta yang bermuara menuju laut Jawa (Wikipedia, 2015). Dengan terus bertambahnya jumlah air limbah, saat ini sungai Ciliwung sudah sulit melaklukan self purification untuk "membersihkan" polutan-polutan yang masuk bersama air limbah, sehingga kualitas air sungai Ciliwung terus menurun bahkan saat ini dikelompokkan sudah tercemar berat (BPPT Enjiniring, 2014).

Faktor utama yang menjadikan berhasil tidaknya restorasi sungai adalah pengendalian pencemaran air yang masuk ke lokasi sungai yang akan direstorasi. Salah satu langkah upaya untuk mengendalikan pencemaran adalah dengan pemantauan kualitas air sungai. Pemantauan ini perlu dilakukan secara terus menerus dengan cara menganalisis kualitas air yang masuk atau yang berada pada aliran sungai secara periodik. Saat ini banyak sekali kendala yang dihadapi terkait pemantauan rutin kualitas air sungai secara konvensional yakni diantaranya: jarak dari lokasi ke laboratorium analisa kualitas air yang cukup jauh, kemacetan lalu lintas, dan juga resiko bahaya saat pengambilan sampel langsung di lokasi sungai. Kendala lain yang cukup signifikan adalah total biaya analisa sampel yang cukup mahal untuk pemantauan rutin di banyak titik di aliran sungai.

Upaya yang dapat dilakukan untuk mengefisienkan pemantauan kualitas air, adalah dengan menerapkan sistem online monitoring kualitas air di beberapa lokasi pemantauan, baik di lokasi sumber pencemar, maupun di lokasi aliran sungai itu sendiri. Oleh karena itu Kementerian LHK bekerjasama dengan BPPT akan melakukan penerapan online monitoring kualitas air di beberapa lokasi pemantauan di sumber air limbah maupun di aliran sungai Ciliwung.

Tentu saja penerapan sistem online monitoring kualitas air ini harus dikaji terlebih dahulu sebelum diterapkan. Sebagai langkah awal pengkajian adalah dengan menerapkan percontohan sistem online monitoring pada salah satu lokasi di sungai Ciliwung. Dengan percontohan tersebut nantinya akan didapatkan beberapa kesimpulan mengenai bentuk bangunan pelindung yang cocok, jangka waktu kalibrasi sensor, kendala yang dihadapi, kehandalan sistem, dan upaya untuk meningkatkan kinerja sistem.

\subsection{Tujuan Dan Sasaran}

Tujuan dari kegiatan adalah mengkaji penerapan sistem online monitoring kualitas air di sungai ciliwung dengan cara menerapkan percontohan sistem online monitoring pada salah satu lokasi di sungai Ciliwung. Dari kegiatan ini diharapkan menghasilkan beberapa kesimpulan mengenai: bentuk bangunan pelindung yang cocok, jangka waktu kalibrasi sensor, kendala yang dihadapi, kehandalan sistem, dan upaya untuk meningkatkan kinerja sistem.

\section{METODOLOGI}

Metodologi yang digunakan untuk melaksanakan kegiatan instalasi sistem online monitoring kualitas air ini adalah sebagai mana ditunjukkan oleh Gambar 1 berikut :

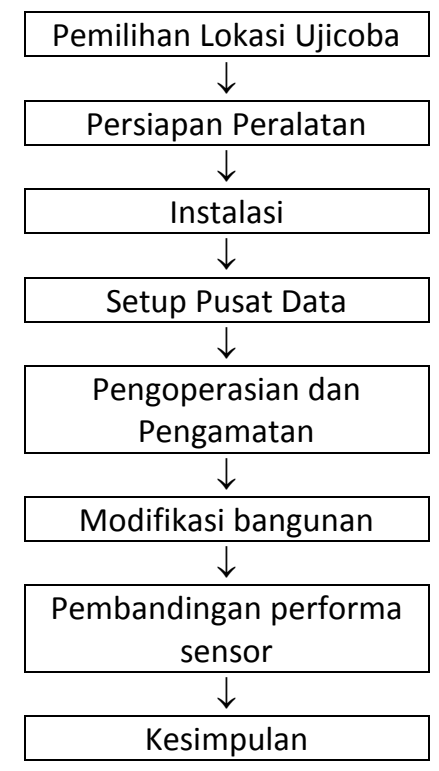

Gambar 1 : Metodologi Instalasi Sistem.

- Survei lokasi dilakukan dengan memilih salah satu lokasi yang cocok untuk pemasangan sistem dengan pertimbangan keamanan, kemudahan dalam pemasangan, dan pengontrolanya.

- Persiapan peralatan dimulai dari: perancangan dan pembuatan bangunan penopang; persiapan perangkat remote terminal unit (RTU); dan persiapan sistem software di pusat data.

- Instalasi dilakukan pada titik lokasi yang telah ditentukan.

- Pengoperasian dan pengamatan di pusat data dilakukan dengan mengoperasikan software SMS gateway untuk mengendalikan data logger dan perangkat lunak database online monitoring.

- Modifikasi bangunan dilakukan ketika sistem mengalami gangguan pada saat sistem telah dijalankan. Modifikasi ini bertujuan agar sistem dapat berjalan dengan baik.

- Pembandingan performa sensor dilakukan dengan mebandingkan hasil pengukuran sensor lain yang sudah dikalibrasi. 


\section{HASIL DAN PEMBAHASAN}

\subsection{Teknologi Online Monitoring Kualitas Air Berbasis GSM}

Teknologi Online Monitoring Kualitas Air Berbasis GSM yang telah dikembangkan oleh BPPT terdiri dari 3 (tiga) komponen utama yakni: Remote Terminal Unit (RTU), Pusat Data, dan Sensor. Cara kerja sistem online monitoring ini adalah dengan mengambil data hasil pengukuran dari sensor yang kemudian diolah oleh data logger pada RTU untuk disimpan dan dikirimkan ke pusat data. Pengiriman data dari RTU ke pusat data adalah dengan menggunakan media SMS (Short Message Service) dengan sinyal GSM.

RTU terdiri dari data logger dan peralatan sumber daya seperti baterai dan panel surya. RTU ini berfungsi untuk melakukan pengumpulan data dari sensor. RTU bertugas untuk memberikan instruksi kepada sensor kapan harus melakukan pengukuran. $R T U$ juga bertugas untuk mengirimkan data hasil monitoring ke pusat data yakni dengan memberi perintah kepada modem GSM yang telah terpasang.

Pusat Data berfungsi untuk mengendalikan RTU dari jarak jauh dan sebagai tempat pengumpulan data. Pusat data terdiri dari Komputer beserta Software SMS Gateway dan Modem GSM.

Sensor Kualitas Air yang digunakan merupakan sensor dengan komunikasi data berbasis serial RS-232.

\subsection{Penentuan Lokasi Ujicoba}

Lokasi pemasangan yang dipilih adalah bagian sungai Ciliwung yang melintas di halaman Masjid Istiqlal dengan koordinat $-6.171404,106.931097$. lokasi ini berada di sebelah barat jembantan pintu selatan komplek. Lokasi ini dipilih dengan pertimbangan sebagai berikut:

- Sinyal GSM di lokasi ini bagus untuk seluruh operator penyedia jaringan

- Akses lokasi mudah

- Lokasi jarang dilewati kendaraan

- Keadaan lokasi mendukung untuk dibuat bangunan sistem onlimo

- Keamanan terjamin karena berada di wilayah komplek yang memiliki penjaga lingkungan.

Gambar 2 adalah lokasi pemasangan sensor kualitas air.

Lokasi komputer server ditempatkan di Gedung Geostech (BPPT) Puspiptek Serpong. Lokasi tersebut dipilih karena memiliki peralatan yang memadahi untuk kebutuhan server seperti: kebutuhan listrik kontinyu (UPS), pendingin ruangan, dan keamanan.

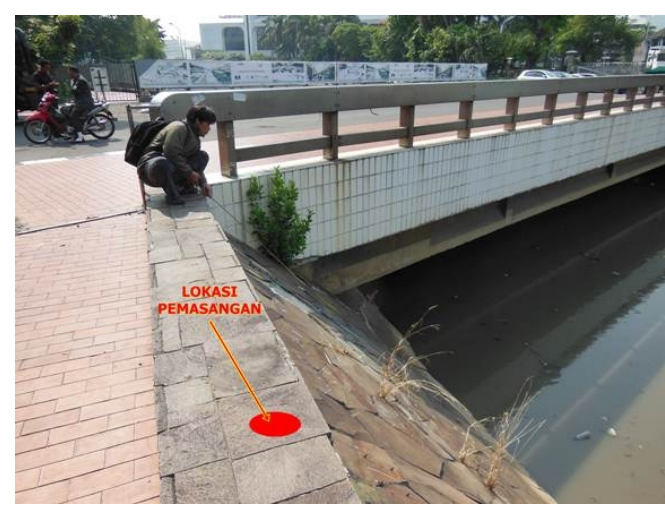

Gambar 2 : Lokasi Sistem Online Monitoring.

\subsubsection{Pemilihan Operator Jaringan GSM}

Untuk memilih operator jaringan GSM maka dilakukan pengujian terhadap kekuatan sinyal GSM di lokasi penempatan sensor, lokasi penempatan data logger dan lokasi pusat data. Pengujiannya dilakukan secara manual, yaitu dengan menggunakan perangkat telepon genggam. Pengujian kekuatan sinyal GSM yang dilakukan meliputi sim card : Simpati, 3, XL, dan IM3. Pengujian dilakukan dengan membandingkan tinggi balok yang menandakan kekuatan sinyal dalam perangkat telepon genggam. Makin tinggi balok sinyalnya maka makin kuat dan baik sinyal tersebut pada posisi lokasi yang diuji. Hasil survey pemilihan operator GSM ditetapkan untuk menggunakan Sim Card Kartu AS dari operator GSM Telkomsel.

\subsection{Persiapan Peralatan}

\subsubsection{Sensor Kualitas Air}

Dengan mempertimbangkan kebutuhan parameter pengukuran, maka sensor yang digunakan adalah sensor multiprobe DKK-TOA WQC-24 dengan 12 parameter pengukuran diantaranya: Temperatur, Conductivity, TDS, Salinity, DO, pH, Turbidity, Depth, SwSG, Ammonium, Nitrate, ORP. Keseluruhan parameter tersebut sudah cukup untuk menentukan status pencemaran sungai. Gambar 3 merupakan sensor multiprobe DKK-TOA WQC-24.

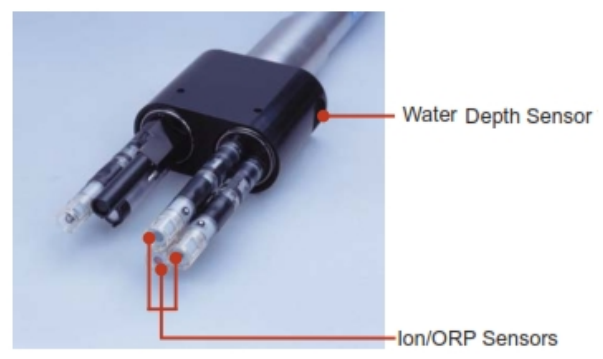

Gambar 3 : Sensor WQC-24 (TOA-DKK, 2015). 


\subsubsection{Data Logger}

Data logger yang digunakan merupakan perangkat versi paling baru dari data logger yang telah dikembangkan oleh BPPT, yakni versi 3.0. Data logger yang dikembangkan memiliki beberapa fitur utama diantaranya: memiliki sistem pengiriman data berbasis SMS dan dapat lebih dari 164 karakter, interval waktu pengiriman dapat disetting dan dimonitoring dari pusat data, delay waktu pengukuran kualitas untuk early warning system hanya 60 detik, status memori dan status pengiriman data dapat dimonitoring dari pusat data, serta memiliki onsite display untuk menampilkan hasil pengukuran setiap saat di lapangan. Adapun spesifikasi teknis sistem data logger yang dikembangkan adalah (Bayu Budiman dan Heru Dwi Wahjono, 2010):

- Serial RS-232 port : 1 main, 3 slave

- 8 channel analog port

- 8 bit optocoupler TTL input, extendable to 40 bit

- 4 bit Transistor output, extendable to 20 bit

- 256 kByte flash memori

- Real Time Clock dan

- $\quad$ Dilengkapi PLC untuk EWS

\subsubsection{Panel Surya dan Battery}

Panel surya yang digunakan berkapasitas 50 Wp dengan tegangan kerja 12 volt sedangkan battery yang digunakan berkapasitas 12 Ah dengan tegangan kerja 12 volt. Berdasarkan sistem yang sudah dipasang dan dikembangkan oleh BPPT Panel surya kapasitas 50 Wp dengan battery 12 Ah 12 volt mampu untuk memenuhi kebutuhan daya data logger setiap hari (Heru Dwi Wahjono dan Bayu Budiman, 2006).

\subsubsection{Komputer dan GSM Modem}

Software SMS Gateway akan berjalan dengan baik pada komputer pentium IV ke atas. Pada penelitian kali ini komputer yang digunakan adalah iCore7.

GSM modem yang digunakan adalah modem dengan interface serial RS-232.

\subsubsection{Sistem Perangkat Lunak}

Sistem perangkat lunak yang dipersiapkan adalah SMS Gateway dan Database Online Monitoring. Kedua software ini dirancang dan dikembangkan agar dapat beroperasi secara bersama-sama dengan integrasi seluruh peralatan online monitoring yang akan dipasang. Software SMS Gateway digunakan sebagai pengendali pengiriman data melalui SMS dan software database digunakan sebagai sistem penyimpan dan penelusuran kembali data monitoring kualitas air. Gambar 4 (LAMPIRAN) merupakan tampilan software SMS Gateway yang digunakan dalam ujicoba ini sedangkan Gambar 5 (LAMPIRAN) merupakan tampilan software databasenya.

Spesifikasi teknis perangkat lunak SMS gateway yang dikembangkan adalah (Heru Dwi Wahjono dan Bayu Budiman, 2006) :

- Multi station monitoring.

- $\quad$ Remote control memakai SMS \& perintah AT.

- Peringatan dini atau Early Warning System.

- Nilai baku mutu kualitas air dapat diset.

- Multi user SMS dan EWS.

- Interval waktu pengukuran dapat diset.

- Interval waktu pengiriman data dapat diset.

- Data record dalam format txt (pipe delimited).

- Terdapat informasi status battery, memori dan sisa pulsa untuk kartu prabayar.

- Terdapat fungsi peringatan dini di komputer (red blink).

Spesifikasi teknis perangkat lunak database online monitoring kualitas air yang dikembangkan adalah :

- Mengelola data stasiun dan data kualitas air.

- Penggunaan bersama file oleh aplikasi SMS Gateway melalui file data dalam format teks.

- Memantau data secara online dan realtime.

- Menampilkan data pengukuran dalam bentuk angka dan grafik analisa.

- Tersedia laporan ringkas, detail dan lengkap.

- Tersedia dokumen elektronik untuk online manual, regulasi dan data baku mutu.

- Penelusuran data : harian / bulanan / stasiun

- Dibuat dalam bahasa Indonesia.

\subsection{Instalasi/Pemasangan Peralatan}

\subsubsection{Pembuatan dan pemasangan Bangunan Pelindung}

Bangunan pelindung merupakan kerangkeng besi yang dipasang pada tiang penyangga. Tiang penyangga tersebut dipasang di atas trotoar. Anak tangga dipasang pada tebing untuk mempermudah pemasangan dan pemeliharaan peralatan sensor. Gambar 6 (LAMPIRAN) adalah sketsa rencana pemasangan peralatan remote terminal unit di titik lokasi pemantuan di sungai Ciliwung segmen Istiqlal.

Secara umum pembuatan bangunan pelindung ini menggunakan teknik las listrik untuk menyambung potongan besi dan menggunakan mur-baut untuk menggabungkan. Tiang dibuat dengan menggunakan besi hollow $40 \mathrm{~mm}$ x $60 \mathrm{~mm}$ yang panjangnya sebesar $309 \mathrm{~cm}$. Fondasi tiang dibuat dengan menggunakan dinabolt yang ditanamkan pada sisi-sisi trotoar. Dinabolt tersebut digunakan sebagai tempat dipasangnya kupingan yang terdapat pada kaki tiang. 
Kaki tiang dibuat dengan menggunakan besi hollow dengan ukuran yang sama dengan tiang. Kaki tiang dibuat menyelimuti sisi trotoar bagian luar yang masing-masing sisinya dilengkapi dengan dinabolt. Gambar 7 Nomor 1 merupakan bangunan tiang penopang sedangkan Nomor 2,3, dan 4 merupakan gambar pemasangan kaki tiang pada fondasi yang merupakan dinabolt.

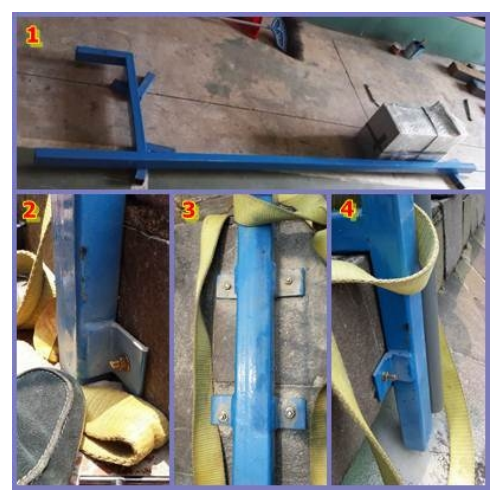

Gambar 7 : Bangunan Tiang Penopang.

Kerangkeng pelindung boks panel dibuat dengan menggunakan besi siku $3 \mathrm{~cm}$ × $3 \mathrm{~mm}$ sebagai kerangkanya dan besi 9 sebagai jerujinya. Kerangkeng yang dibuat memiliki ukuran $50 \mathrm{~cm}$ x $30 \mathrm{~cm}$ x $60 \mathrm{~cm}$. Ukuran tersebut telah disesuaikan dengan ukuran boks panel.

Tangga dibuat dengan menggunakan besi hollow berukuran $4 \mathrm{~cm} \times 4 \mathrm{~cm}$ dengan ukuran anak tangga $25 \mathrm{~cm}$. Tangga yang dibuat memiliki 6 kaki yang masing masing kaki memiliki kupingan. Fondasi tangga dibuat dengan menggunakan dinabolt yang ditanamkan pada dinding tebing. Dinabolt tersebut digunakan sebagai tempat dipasangnya kupingan kaki tangga. Gambar 8 Nomor 1 merupakan kerangkeng pelindung ketika proses pembuatan dan Nomor 2 merupakan tangga yang telah dipasang.

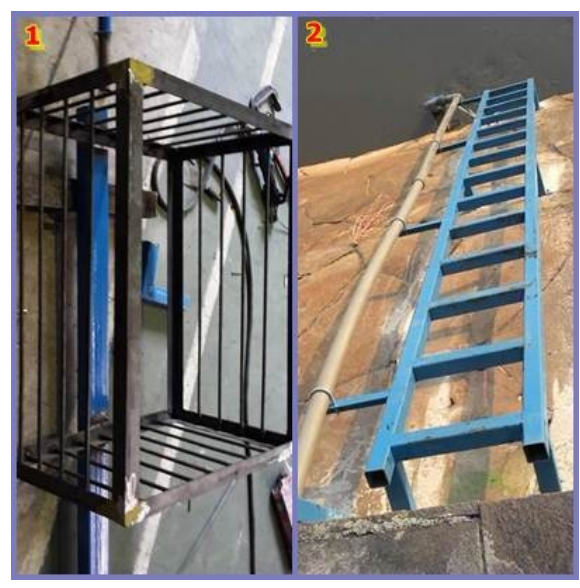

Gambar 8 : Kerangkeng Pelindung Dan Tangga.

\subsubsection{Pemasangan komponen ke bangunan pelindung}

Boks panel data logger dipasang ke tiang dengan menggunakan mur baut yang telah diseting sebelumnya. Mur dan baut berjumlah 4 pasang yang terletak pada bagian belakang mounting plate di dalam box panel.

Panel surya dipasang pada bagian ujung paling atas tiang penyangga dengan menggunakan bracket panel surya. Bracket panel ditopang oleh besi holow berdiameter 4,5 cm yang kemudian diletakan/dimasukkan di atas besi holow dengan diameter $4 \mathrm{~cm}$ yang telah terpasang fix pada tiang. Mur baut ukuran $5 \mathrm{~mm} 2 \mathrm{~cm}$ digunakan untuk memperkuat sambungan besi bracket dan tiang.

Data Logger dan handheld LCD dipasang menempel pada mounting plate di dalam box panel dengan menggunakan mur dan baut sedangkan battery diletakan di depan data logger bagian bawah. Setelah data logger terpasang, kabel dipasang dan dimasukan ke dalam pipa kabel hingga ke bagian ujung pipa di atas permukaan air. Gambar 9 merupakan hasil perakitan boks panel, panel surya, dan data logger.

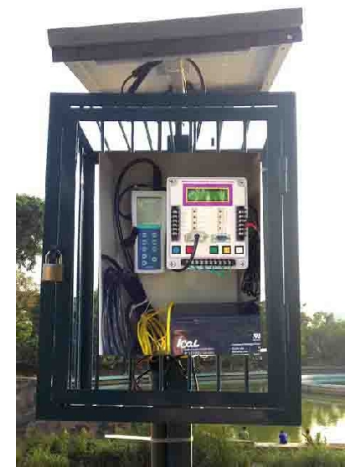

Gambar 9 : Perakitan Boks Panel Dan Panel Surya.

\subsubsection{Pemasangan Sensor}

Pipa kabel perlu dipasang untuk melindungi kabel data yang menghubungkan sensor dan data logger. Pipa kabel ini merupakan pipa PVC 1 1/4 dengan komponen tambahan berupa elbow $45^{\circ}$ dan klem besi pejal $1 \frac{1 / 4}{4}$.

Pipa kabel dipasang di antara box panel dan lantai pembatas sungai kemudian dipasang ellbow $45^{\circ}$ yang selanjutnya dipasangi pipa lagi dari dinding pembatas hingga diatas permukaan air. Pipa kabel dari dinding batas sungai sampai permukaan air dipasang pada tangga dengan menggunakan klem besi ukuran 1 $1 / 4 "$.

Untuk melindungi sensor dari benturan sampah yang mengalir di sungai, perlu dibuat pipa pelindung sensor. Pipa pelindung sensor ini dibuat dengan menggunakan pipa PVC 5" yang diberi lubang-lubang 
dengan ukuran 1/2" 3/4" dengan kerapatan lubang kurang lebih 1 $2 \mathrm{~cm}$. Sensor dimasukan ke dalam pipa pelindung ini dan diberi bantalan gabus dengan ukuran $5^{\prime \prime}$ agar sensor stabil terhadap guncangan.

Setelah unit sensor dimasukkan ke dalam pipa pelindung PVC, berikutnya adalah memasangkan kabel sensor ke sensor. Tali tambang ukuran $5 \mathrm{~mm}$ dipasang untuk menambah kekuatan sensor agar jika sensor lepas, tali tambang masih bisa menahan sensor sehingga sensor tidak jatuh. Tali tambang diletakan bersama kabel di dalam pipa dan diikatkan ke dalam box panel. Pemasangan pelindung sensor ke pipa dilakukan dengan menggunakan pipa reducer (flock sock) 5-4", reducer 4-3"'”, reducer 3-1 1/4". Water Mur 1 $1 / 4$ " dipasang di antara pelindung sensor dan pipa agar memudahkan pembongkaran sensor untuk pemeliharaan (maintenance).

Gambar 10 Nomor 1 merupakan pemasangan sensor ke pipa pelindung sedangkan Gambar 10 Nomor 2 adalah ketika sensor telah terpasang pada pipa pelindung. Gambar 10 Nomor 3 merupakan hasil pemasangan pipa pelindung pada sungai.

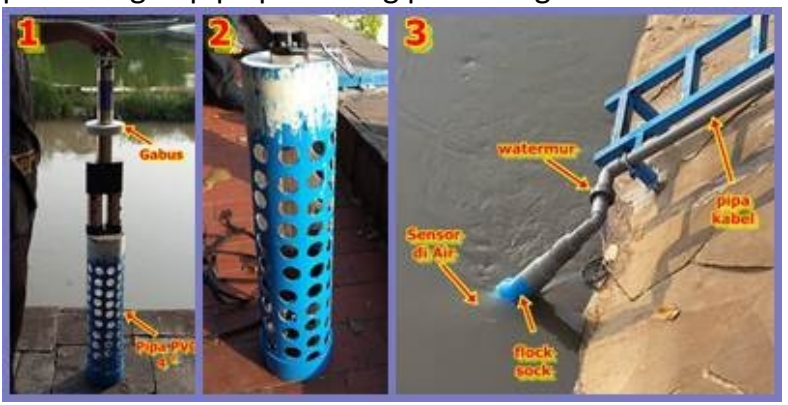

Gambar 10 : Perakitan Dan Pemasangan Pelindung Sensor.

Gambar 11 berikut ini adalah gambar keseluruhan hasil pemasangan akhir sistem sebelum dikalukan modifikasi.

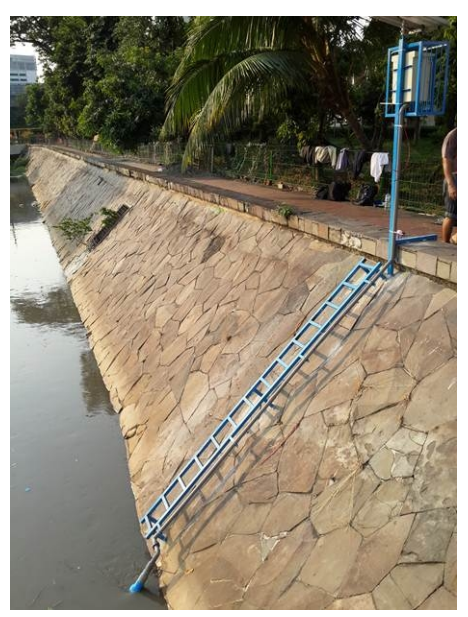

Gambar 11 : Hasil Pemasangan Akhir Bangunan Online Monitoring.

\subsubsection{Setup Pusat Data}

Interval waktu periodik yang diset adalah 20 menit dan interval waktu peringatan dininya 45 detik. Selama ujicoba fitur peringatan dini tidak diaktifkan karena kondisi kualitas air di lokasi pemantauan yang memang sudah jelek. Sistem komunikasi antara remote terminal unit (data logger) dan pusat data menggunakan jaringan komunikasi GSM dengan operator TELKOMSEL. Adapun nomor simcard perangkat GSM modemnya adalah sebagai berikut :

- No. Data Logger : 085110403231

- No. Data Center : 085110406131

\subsection{Modifikasi, Hasil Pengukuran dan Pembahasan}

Dalam ujicoba online monitoring ini terdapat beberapa perubahan struktur bangunan terutama pada bagian pelindung sensor. Perubahan struktur tersebut dilakukan karena munculnya beberapa kendala ketika ujicoba dilakukan.

Perubahan struktur pelindung sensor yang pertama kali dilakukan adalah merubah struktur pemasangan sensor yang sebelumnya rigid atau kaku terhadap muka air menjadi struktur yang movable mengikuti tinggi muka air. Perubahan struktur ini dilakukan karena struktur lama mengalami permasalahan yakni ketika level air sungai turun, sensor menggantung ke udara sehingga yang diukur adalah parameter udara diatas sungai, sedangkan ketika air naik, sensor akan mengukur bagian aliran yang bawah sehingga sensor cepat terkotori oleh lumpur.

Struktur pemasangan sensor yang movable ini dibuat dengan menggunakan teknik pelampung. Sensor dipasang pada pelampung sehingga sensor akan bergerak sesuai pelampung yakni mengikuti muka air. Sensor dan pelampung tersebut tentu saja dilindungi oleh pelindung yang memungkinkan air bebas mengalir melewati sensor dan memungkinkan pelampung dapat bergerak naik turun.

Pelampung dibuat dengan menggunakan pipa PVC 6" dan 2" sedangkan pelindung sensor dibuat dengan menggunakan pipa 8 ". Pelindung sensor tersebut berukuran panjang 1,5 $\mathrm{m}$. Pelampung dibuat menyerupai tabung pejal dengan lubang pada poros tabung secara aksial. Bagian pejal dari pelampung tersebut berisi stirofoam sehingga meskipun kemasukan air, pelampung akan tetap mengapung. Sedangkan lubang pada tabung merupakan sisi dalam pelampung yang merupakan PVC 2". Lubang tersebut adalah tempat peletakan batang sensor akan tetapi probe sensor tetap berada diluar lubang. Pelindung sensor diberi lubang dengan diameter $1 / 2$ " hingga $3 / 4$ " dengan kerapatan 2-3 cm. Pelindung sensor tersebut memiliki ketebalan kurang lebih $0,5 \mathrm{~cm}$ sehingga 
relatif lebih kuat menahan benturan sampah sungai. Gambar 12 merupakan sketsa rancangan pelampung yang dibuat.

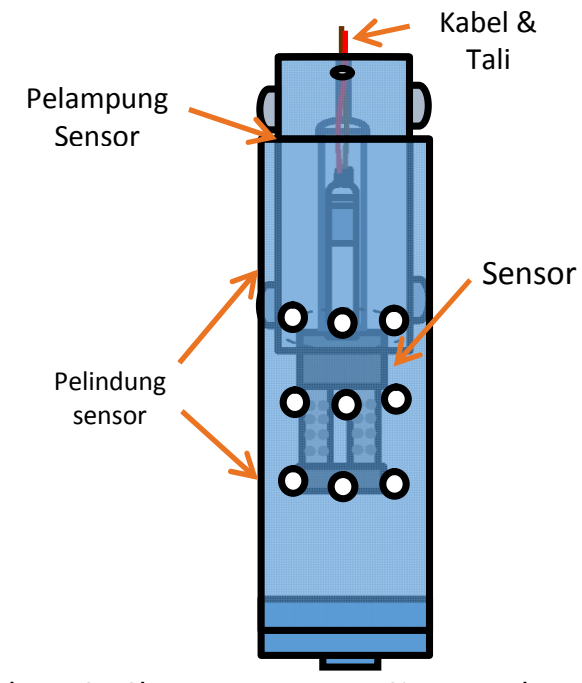

Gambar 12 : Sketsa Rancangan Sistem Pelampung (BPPT Enjiniring, 2014).

Dalam pemasangan struktur yang baru ini, pelindung sensor dipasang ke dinding sungai dengan menggunakan kerangka besi UNP 65 dan diperkuat dengan kabel sling. Pelindung sensor dipasang ke besi UNP dengan menggunakan klem pipa 8" sedangkan besi UNP dipasang di dinding dengan menggunakan dinabolt. Gambar 13 Nomor 1 merupakan hasil pemasangan dari struktur pelampung sedangkan Gambar 13 Nomor 2 adalah gambaran ketika pengangkatan sensor saat maintenance.

Dalam perkembangan selanjutnya struktur sensor tersebut mengalami beberapa kekurangan dan permasalahan.

Kekurangan yang dihadapi adalah ketidakpraktisan ketika akan melakukan kalibrasi sensor di lokasi. Jika ketersediaan sensor lebih dari satu maka sensor yang telah dikalibrasi dapat langsung digunakan untuk mengganti sensor yang lama. Jika sensor hanya satu, maka mau tidak mau sensor harus dikalibrasi di lokasi karena jika sensor harus dibawa ke lab terlebih dahulu akan banyak data kualitas air yang terlewat. kalibrasi dengan struktur ini dilakukan dengan mengankat pelindung sensor (Gambar 18), kemudian mengeluarkan sensor dan mencelupkan ke larutan standar kalibrasi. Langkah-langkah kalibrasi tersebut hanya baik dilakukan ketika level air tidak melebihi batang penyangga pelindung sensor. Jika level air berada diatas batang tersebut maka akan sulit untuk mengangkat pelindung sensor yang berada di bawah permukaan air. Gambar 14 memperlihatkan ketika level air berada diatas batang penyangga dan permasalahan sampah yang masih terjadi.

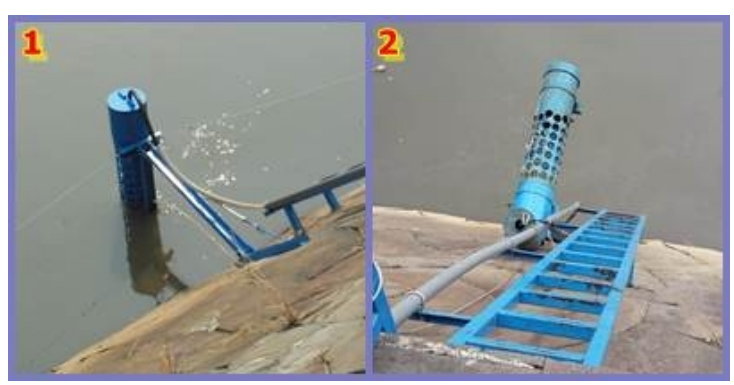

Gambar 13 : Hasil Pemasangan Struktur Pelampung.

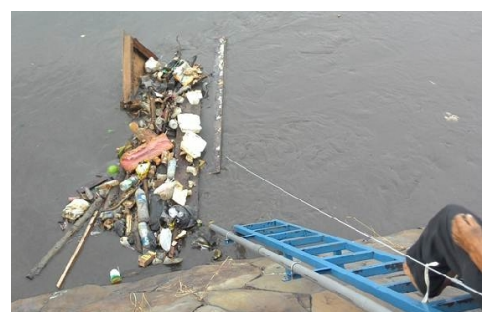

Gambar 14 : Keadaan Ketika Level Air Di Atas Pelindung Sensor.

Perubahan struktur yang kedua adalah dengan membuat pelindung sensor yang lebih tinggi dari sebelumnya yakni dengan ketinggian diatas rata-rata ketinggian maksimal permukaan air sungai dan menambahkan bangunan berupa jembatan untuk mengakses pipa pelindung sensor. Rata-rata ketinggian maksimal diperoleh dari hasil wawancara pengelola setempat dan didukung oleh keberadaan bekas air yang ditimbulkan pada dinding sungai. Pipa pelindung yang baru juga dibuat dengan menggunakan pipa dengan ukuran diameter yang sama seperti sebelumnya yakni pipa PVC 8" namun lebih panjang yakni $3 \mathrm{~m}$. Sock drat dalam 8 " beserta dengan dop drat luar 8" dipasang pada bagian atas pipa untuk memudahkan dalam pengambilan sensor nantinya. Rangka jembatan dibuat dengan menggunakan besi hollow $3 \times 3$ sedangkan lantai jembatan dibuat dengan menggunakan boardesk alumunium dengan ketebalan $4 \mathrm{~mm}$. Dalam struktur ini kabel sensor diletakkan pada kabel ducting yang sebelumnya telah dipasang pada sisi samping boardesk. Plat lingkaran PVC dengan tebal $1 \mathrm{~cm}$ dan diameter 1 meter dipasang pada pipa pelindung untuk menghalau sampah. Gambar 15 memperlihatkan perubahan struktur yang terakhir dari penelitian ini.

Dengan struktur ini langkah untuk mengambil sensor dilakukan dengan membuka dop drat luar kemudian mengeluarkan sensor beserta pelampung dari dalam pipa. Setelah sensor dikeluarkan, sensor dapat langsung diganti atau dibawa ke tepi sungai untuk dilakukan kalibrasi secara langsung menggunakan Hand-Held yang terpasang pada datalogger. Dengan struktur ini langkah untuk melakukan perawatan sensor menjadi lebih mudah 
jika dibandingkan dengan struktur-struktur sebelumnya.

Dalam pengamatan selama kurang lebih sebulan, plat lingkaran PVC efektif dalam menanggulangi permasalahan terhadap sampah yang terbawa arus sungai. sampah yang menabrak plat tersebut sulit untuk tersangkut pada plat sehingga pipa pelindung sensor lebih bersih.

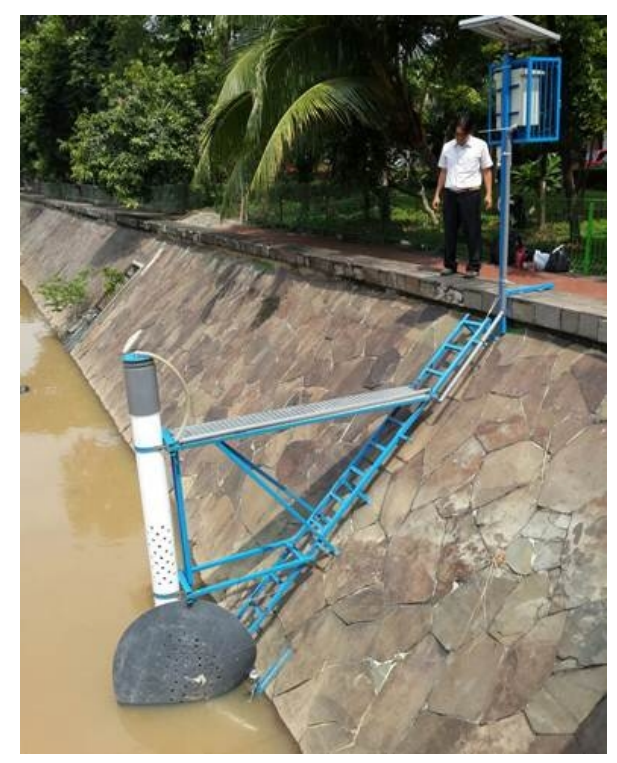

Gambar 15 : Hasil Terakhir Bangunan Online Monitoring ISTIQLAL.

\subsubsection{Hasil Pengukuran}

Ujicoba dilaksanakan dari tanggal 2 November 2014 dan berakhir pada tanggal 16 Desember 2014. Urutan kegiatan yang dilakukan adalah sebagai berikut:

- 02 November 2014: pemasangan awal peralatan untuk ujicoba

- 09 November 2014: perubahan pertama struktur sensor, perawatan dan kalibrasi sensor

- 19 November 2014: perawatan dan kalibrasi sensor nitrat

- 22 November 2014: perubahan yang ke dua struktur sensor, perawatan dan kalibrasi sensor

Pada saat perawatan dan kalibrasi tanggal 9 November, sensor telah tertutupi lumpur akan tetapi lumpur tersebut sangat mudah dihilangkan dengan cara diguyur air bersih. Untuk tanggal 19 dan 22, sensor tampak lebih bersih karena telah menggunakan sistem pelampung. Gambar 16 Nomor 1 menunjukkan sensor ketika tertutupi lumpur sebelum menggunakan sistem pelampung sedangkan Gambar 16 Nomor 2 setelah menggunakan pelampung. Pada saat ujicoba, kekeruhan sungai diperparah dengan adanya kegiatan pengerukan sungai ciliwung pada area sekitar jalan inspeksi RSCM ke utara.

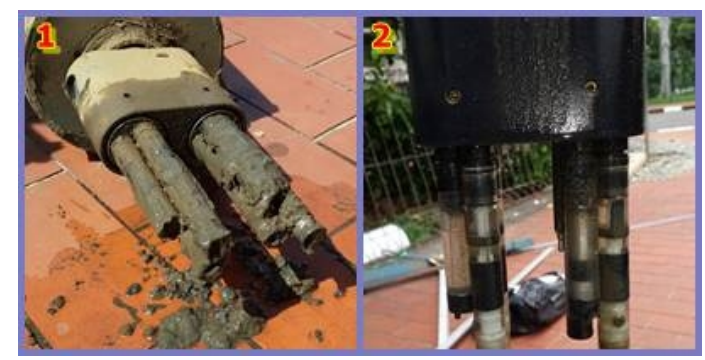

Gambar 16 : Sensor Ketika Tertutupi Lumpur.

Gambar 17 dan Gambar 18 (LAMPIRAN) adalah grafik rata-rata harian hasil pengukuran kualitas air dari tanggal $2 \sim 30$ November 2014 dan tanggal $1 \sim 16$ Desember 2014 untuk parameter DO dan pH. Pada tanggal 9 November 2014, parameter DO (garis biru) mengalami kenaikan di angka sekitar 2, hal ini dikarenakan pada tanggal tersebut terjadi hujan sehingga terjadi pengenceran. Begitu juga dengan tanggal 2 Desember dan 12 Desember sampai Tanggal 16 Desember terjadi kenaikan DO karena hujan. Sedangkan untuk parameter $\mathrm{pH}$ selama 1,5 bulan dari tanggal 2 November sampai 16 Desember masih berada pada kisaran baku mutu $6 \sim 7$.

Gambar 19 dan Gambar 20 (LAMPIRAN) adalah grafik rata-rata harian hasil pengukuran kualitas air dari tanggal $2 \sim 30$ November 2014 dan tanggal $1 \sim 16$ Desember 2014 untuk parameter Turbidity (garis biru) dan TDS. Pada tanggal 9 November, 4 Desember, dan 8 16 Desember 2014 terjadi penurunan kekeruhan air karena turunnya hujan.

Gambar 21 (LAMPIRAN) menunjukkan hasil pengukuran rata-rata harian $2 \sim 30$ November 2014 untuk parameter Nitrat dengan grafik berskala 2000 $\mathrm{mg} / \mathrm{l}$. Pada tampilan grafik tersebut terlihat hasil pengukuran parameter nitrat mengalami anomali kenaikan yang drastis pada tanggal $9 \sim 19$ November 2014 yakni 100000 mg/l nitrat. Hasil pengamatan menunjukkan sensor telah tertutupi lapisan minyak yang menempel pada probe nitrat, sehingga mengganggu proses pengukuran nitrat. Perawatan dan kalibrasi sensor dilakukan pada tanggal 19 November 2014 dan hasil pengukuran parameter nitrat kembali normal. Data hasil pengukuran setelah dikalibrasi ulang tanggal 20 November 2014 hingga akhir pengujian tanggal 16 Desember 2014 cenderung menurun.

Gambar 22 (LAMPIRAN) menunjukkan hasil pengukuran rata-rata harian $1 \sim 16$ Desember 2014 untuk parameter Nitrat dengan grafik berskala 0,1 $\mathrm{mg} / \mathrm{l}$.

Gambar 23 (LAMPIRAN) merupakan grafik ratarata harian hasil pengukuran kualitas air dari tanggal 2 30 November 2014 untuk parameter Amonia dengan hasil pengukuran relatif stabil berkisar antara 0.05 $0.2 \mathrm{mg} / \mathrm{l}$. Sedangkan Gambar 24 (LAMPIRAN) 
merupakan grafik rata-rata harian hasil pengukuran kualitas air dari tanggal $1 \sim 16$ Desember 2014 untuk parameter Amonia dengan hasil pengukuran relatif stabil berkisar antara $0.1 \sim 0.5 \mathrm{mg} / \mathrm{l}$.

\subsubsection{Hasil Pembandingan Sensor}

Untuk membanding kinerja sensor yang telah dipasang di lokasi selama sebulan maka dilakukan pengukuran menggunakan sensor lain yang sejenis. Kegiatan ini bertujuan untuk mengetahui nilai hasil pengukuran dari kedua sensor, sehingga dapat disimpulkan untuk kondisi air seperti di Sungai Ciliwung segmen Istiqlal harus dikalibrasi berapa kali selama 1 bulan pengoperasian. Tabel 1 berikut ini adalah hasil pengukuran menggunakan kedua sensor tersebut.

Tabel 1 : Perbandingan Hasil Pengukuran Online Dengan Sensor Pembanding.

\begin{tabular}{|l|l|c|c|c|}
\hline No. & \multicolumn{1}{|c|}{ Parameter } & Satuan & $\begin{array}{c}\text { Sensor } \\
\text { Terpasang }\end{array}$ & $\begin{array}{c}\text { Sensor } \\
\text { Pemband } \\
\text { ing }\end{array}$ \\
\hline 1. & Tanggal & & $\begin{array}{c}27 / 11 / 201 \\
4\end{array}$ & $\begin{array}{c}27 / 11 / 2 \\
014\end{array}$ \\
\hline 2. & Jam & & $03: 16$ & $03: 09$ \\
\hline 3. & Temperatur & ${ }^{\circ} \mathrm{C}$ & 29.00 & 28.8 \\
\hline 4. & $\begin{array}{l}\text { Conductifity/D } \\
\text { HL }\end{array}$ & $\mu \mathrm{S} / \mathrm{cm}$ & 24.3 & - \\
\hline 5. & Salinitas & $\%$ & 0.01 & 0.10 \\
\hline 6. & TDS & $\mathrm{g} / \mathrm{l}$ & 0.10 & 0.20 \\
\hline 7. & DO & $\mathrm{mg} / \mathrm{l}$ & 0.00 & 0.05 \\
\hline 8. & pH & 7.16 & 7.35 \\
\hline 9. & Turbidity & $\mathrm{NTU}$ & 75.8 & 72.4 \\
\hline 10. & SwSG & $\delta \mathrm{t}$ & 0.00 & 0.00 \\
\hline 11. & Depth & $\mathrm{m}$ & 0.50 & 0.50 \\
\hline 12. & Amonia & $\mathrm{mg} / \mathrm{l}$ & 0.51 & 4.51 \\
\hline 13. & Nitrat & $\mathrm{mg} / \mathrm{l}$ & 0.08 & 0.00 \\
\hline 14. & ORP & $\mathrm{mV}$ & -113 & 78 \\
\hline
\end{tabular}

Sensor terpasang dan sensor pembanding menggunakan merk dan tipe yang sama. Sensor terpasang sudah beroperasi selama 1 bulan dengan 2 kali dilakukan tindakan perawatan dan kalibrasi. Saat dilakukan perbandingan, sensor ini sudah 2 minggu beroperasi dari terakhir dikalibrasi. Sedangkan sensor pembanding yang digunakan adalah yang masih baru namun sudah dikalibrasi sebelum digunakan. Dari hasil pengukuran oleh kedua sensor dapat diketahui bahwa hasil pengukuran untuk parameter Salinitas, TDS, DO dan Amonia menunjukkan hasil yang cukup berbeda. Hal ini dapat disimpulkan bahwa untuk probe parameter tersebut dalam 2 minggu telah mengalami penurunan kinerja.

\section{KESIMPULAN}

Kesimpulan yang dapat diambil dari kegiatan ujicoba sistem online monitorung di Sungai Ciliwung segmen Masjid Istiqlal adalah sebagai berikut :

- Lokasi yang dipilih yakni kawasan komplek Masjid Istiqlal merupakan tempat yang baik untuk melakukan ujicoba sistem online monitoring ini.

- Sistem sumber daya listrik tidak mengalami gangguan apapun selama ujicoba dilakukan.

- $\quad$ Sistem komunikasi data beserta software SMS Gateway berjalan dengan baik selama ujicoba dilakukan.

- Bangunan penopang boks panel dan panel surya berupa besi hollow sangat praktis dan efisien untuk dipakai jika pinggiran sungai berupa tanggul beton.

- Sampah sungai Ciliwung merupakan problem yang serius yang dapat mengganggu dan merusak peralatan yang dipasang di badan sungai.

- Sistem pelampung cukup baik untuk untuk mengatasi dinamika level air sungai ciliwung.

- Sensor sebaiknya dikalibrasi minimal 2 minggu sekali karena selama 2 minggu sensor telah mengalami penurunan kinerja.

- $\quad$ Probe Nitrat membutuhkan penanganan khusus karena sangat mudah tertutupi lapisan minyak yang akan menyebabkan kesalahan dalam pengukuran.

\section{SARAN}

- Untuk pemasangan Online Monitoring Sungai Ciliwung di wilayah selain Istiqlal sebaiknya menggunakan bangunan yang tepat dengan jenis tanah atau kontur beton.

- Akan lebih aman jika terdapat sistem penghalang sampah yang dipasang agak jauh dari sensor.

- Sebaiknya untuk sensor yang selalu tercelup dalam Sungai Ciliwung dilengkapi dengan pembersih otomatis yang dapat bekerja setiap saat.

\section{DAFTAR PUSTAKA}

- Wikipedia, Ensiklopedia Bebas, http:// http://id.wikipedia.org/wiki/Ci_Liwung, 2015

- TOA-DKK Corporation, Dokumen Teknis, Water Quality Meter Model WQC-24, 2015

- Pemkot DKI Jakarta, Situs Resemi Pemerintah Kota Jakarta, Pemkot DKI Jakarta, Situs Resemi Pemerintah Kota DKI Jakarta, 2015

- Tempo.CO, "Sebanyak 73 Persen Sungai Di Indonesia Tercemar", 4 mei 2015, Situs Resmi Tempo, 
http://bisnis.tempo.co/read/news/2014/06/16/0 90585396/Sebanyak-73-Persen-Sungai-diIndonesia-Tercemar

- Kementerian Lingkungan Hidup, "Ground Breaking Demonstrasi Proyek Restorasi Sungai Ciliwung", 4 mei 2015, Situs Resmi Kementerian Lingkungan Hidup, http://www.menlh.go.id/groundbreakingdemonstrasi-proyek-restorasi-sungai-ciliwung/

- Heru Dwi Wahjono dan Bayu Budiman, Sistem Manajemen Komunikasi Data Jarak Jauh Berbasis Teknologi SMS dan Radio Telemetri Untuk Pemantauan Kualtias Air, JTL Vol 7 No. 2 Mei 2006
- $\quad$ BPPT Enjiniring, Dokumen Teknis, Laporan Akhir Pengkajian Penerapan Monitoring Pengendalian Pencemaran DAS Ciliwung, 2014

- Bayu Budiman dan Heru Dwi Wahjono, Petunjuk Operasional Sistem Onlimo Sungai Kapuas, Pusat Teknonologi Lingkungan - BPPT, 2010

- Heru Dwi Wahjono, Instalasi Sistem Pemantauan Kualitas Air Online Berbasis Gsm Di Sungai Sungai Ciliwung Segmen Istiqlal 


\section{LAMPIRAN}

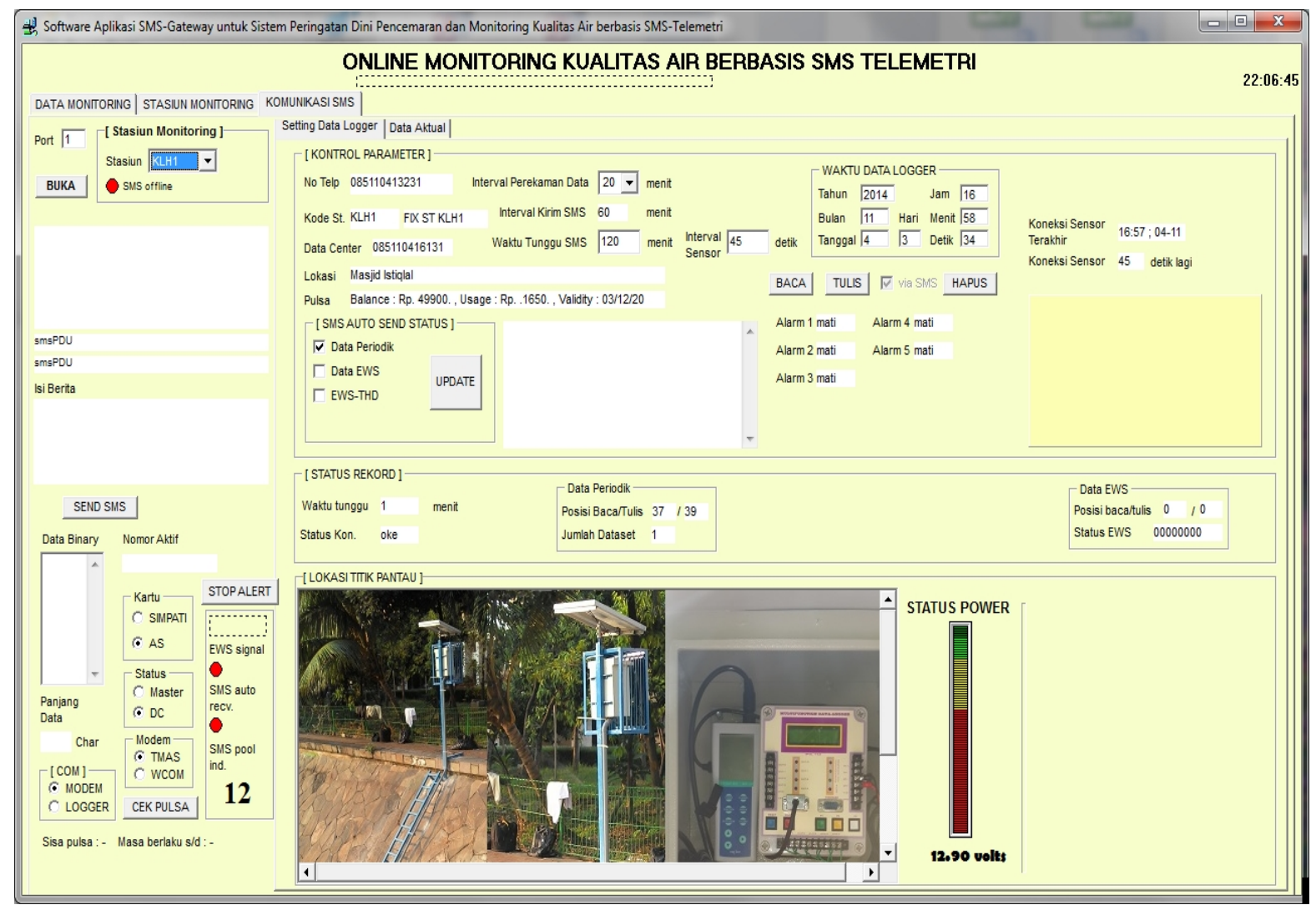

Gambar 4 : Software SMS Gateway (Bayu Budiman dan Heru Dwi Wahjono, 2010).

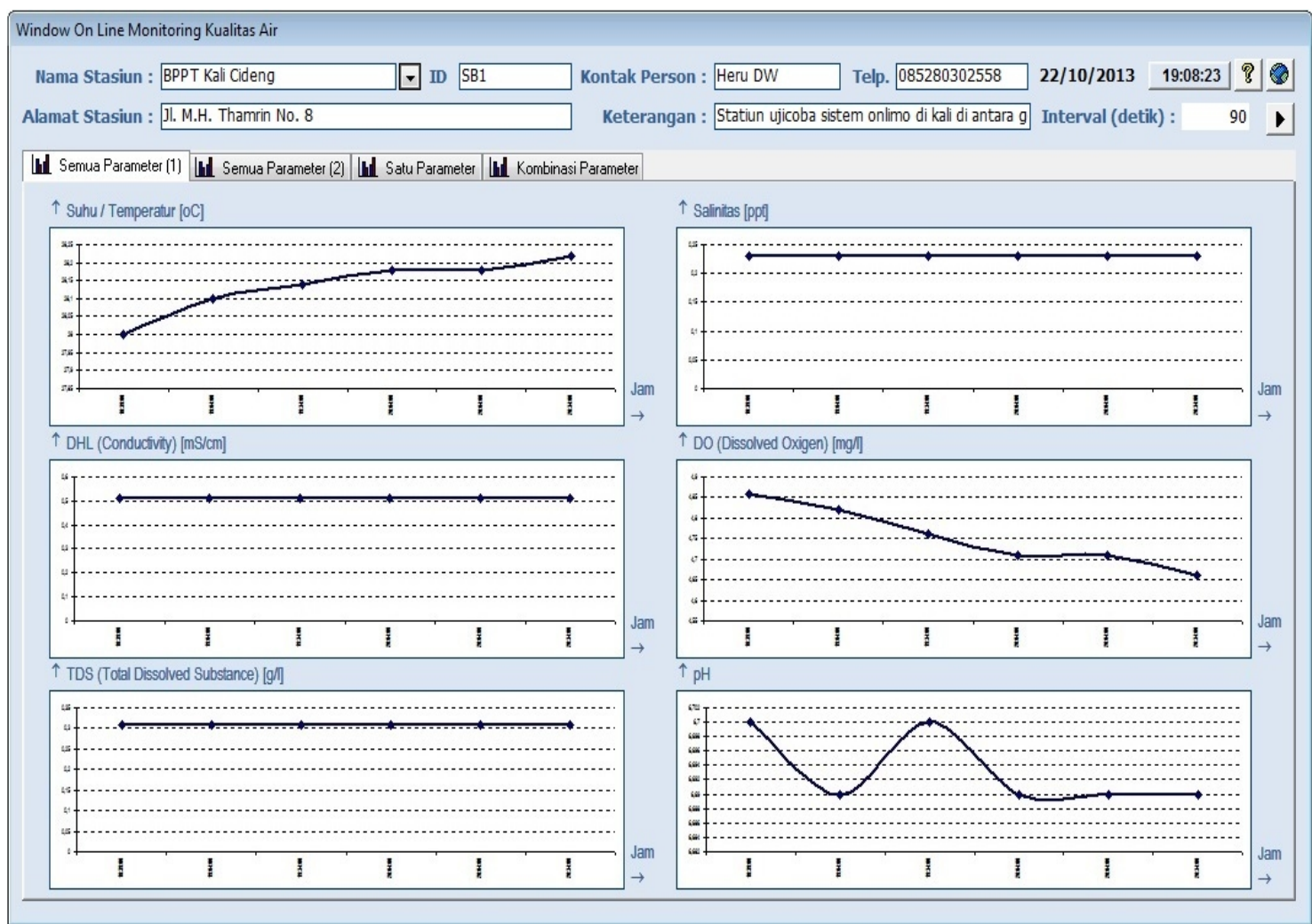

Gambar 5 : Software Database Kualitas Air (Bayu Budiman dan Heru Dwi Wahjono, 2010). 


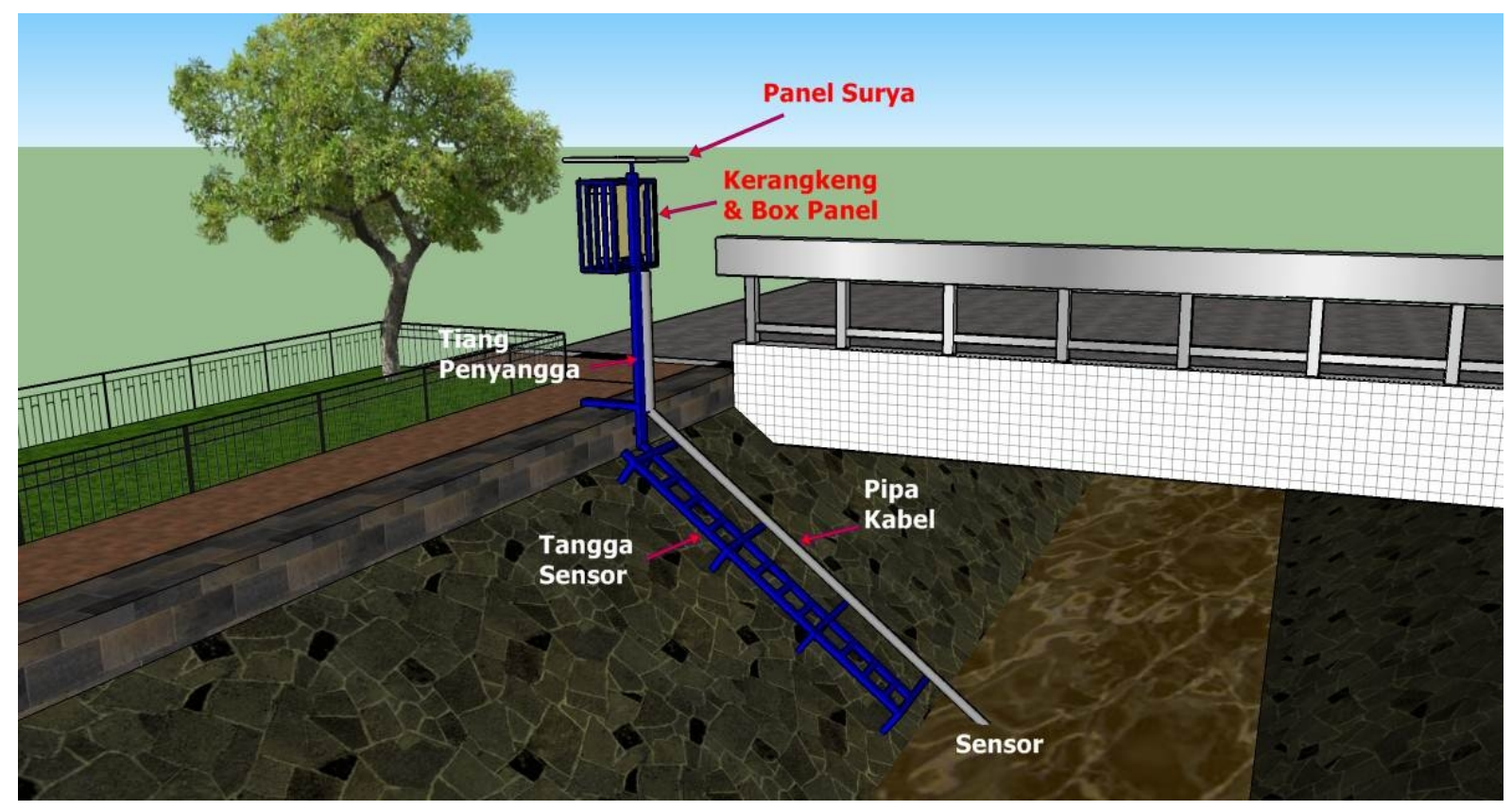

Gambar 6 : Sketsa Bangunan Penopang.

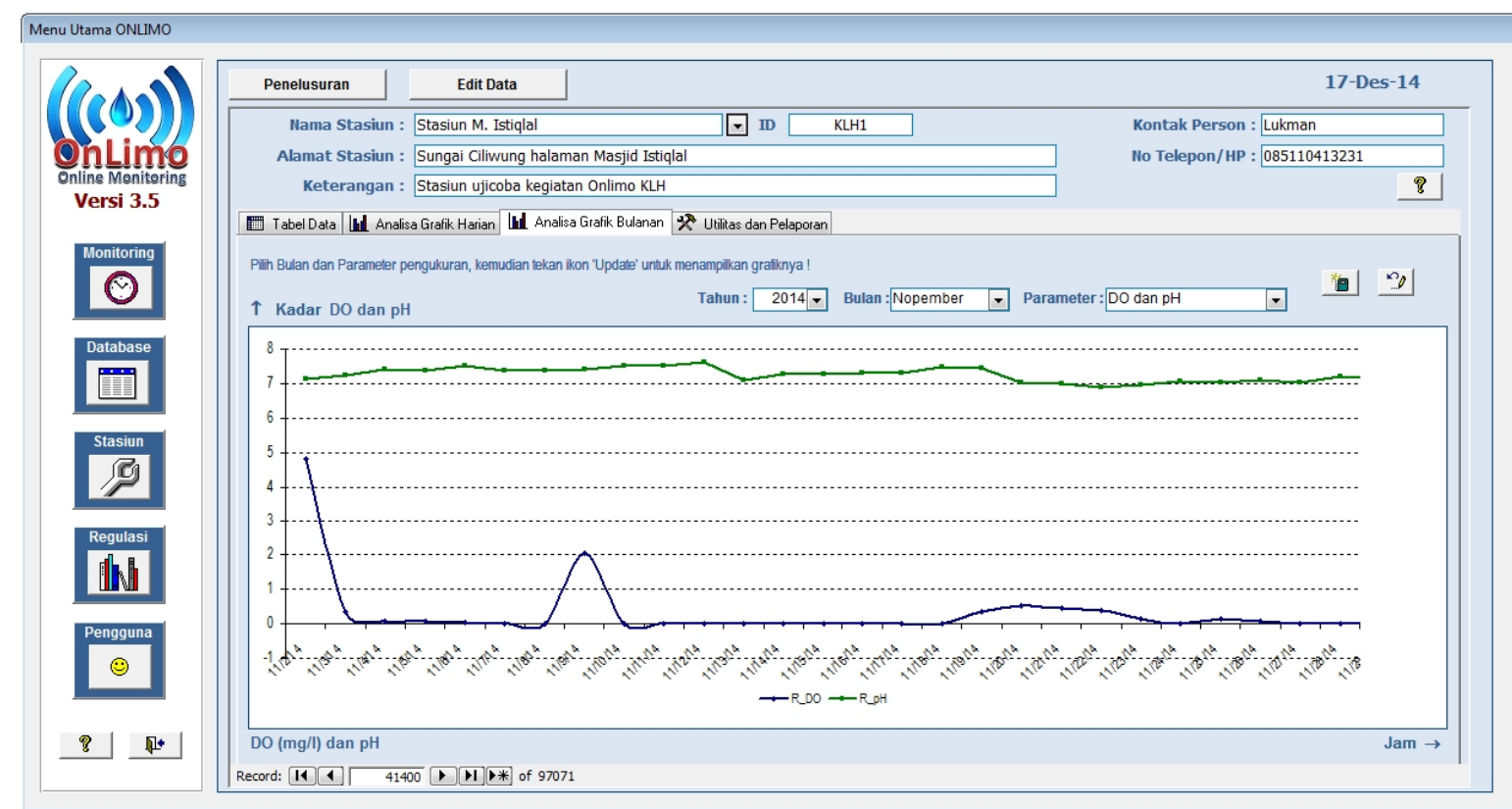

Gambar 17 : Grafik Rata-Rata Harian 2 30 Nov. 2014 Parameter DO dan pH. 


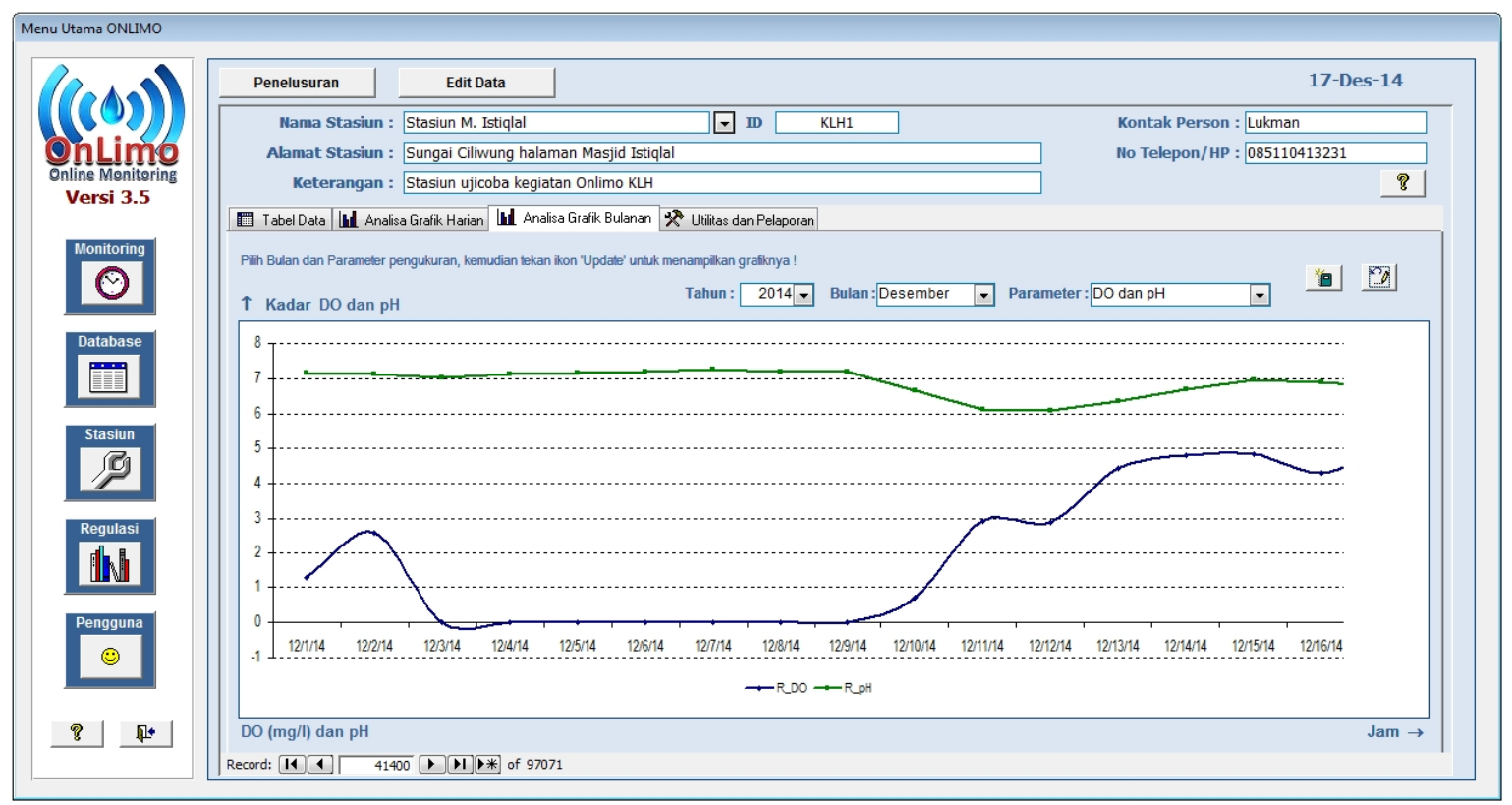

Gambar 18 : Grafik Rata-Rata Harian 1 16 Des. 2014 Parameter DO dan pH.

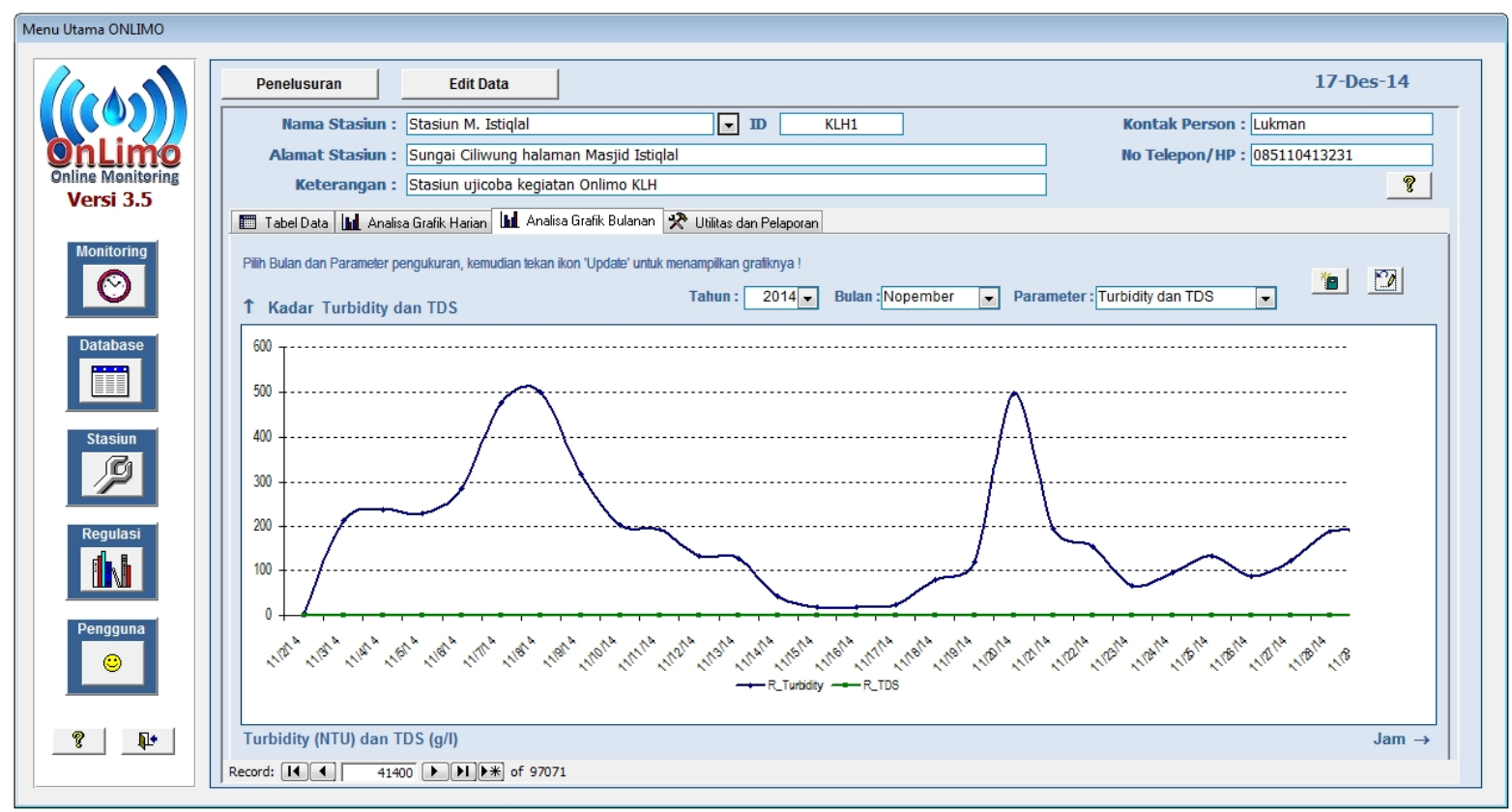

Gambar 19: Grafik Rata-Rata Harian 2 30 Nov. 2014 Parameter Turbidity dan TDS. 


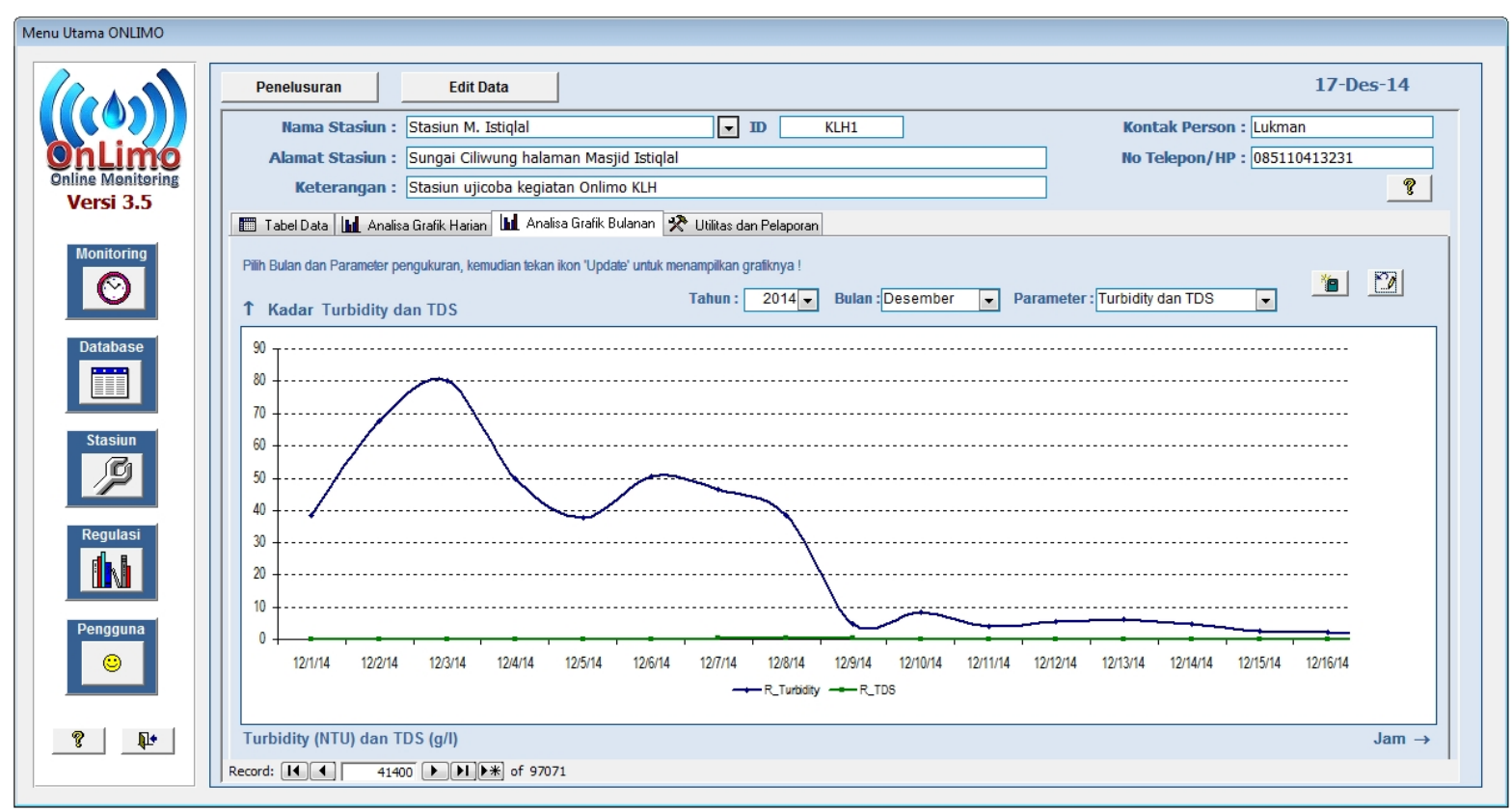

Gambar 20 : Grafik Rata-Rata Harian 1 16 Des. 2014 Parameter Turbidity dan TDS.

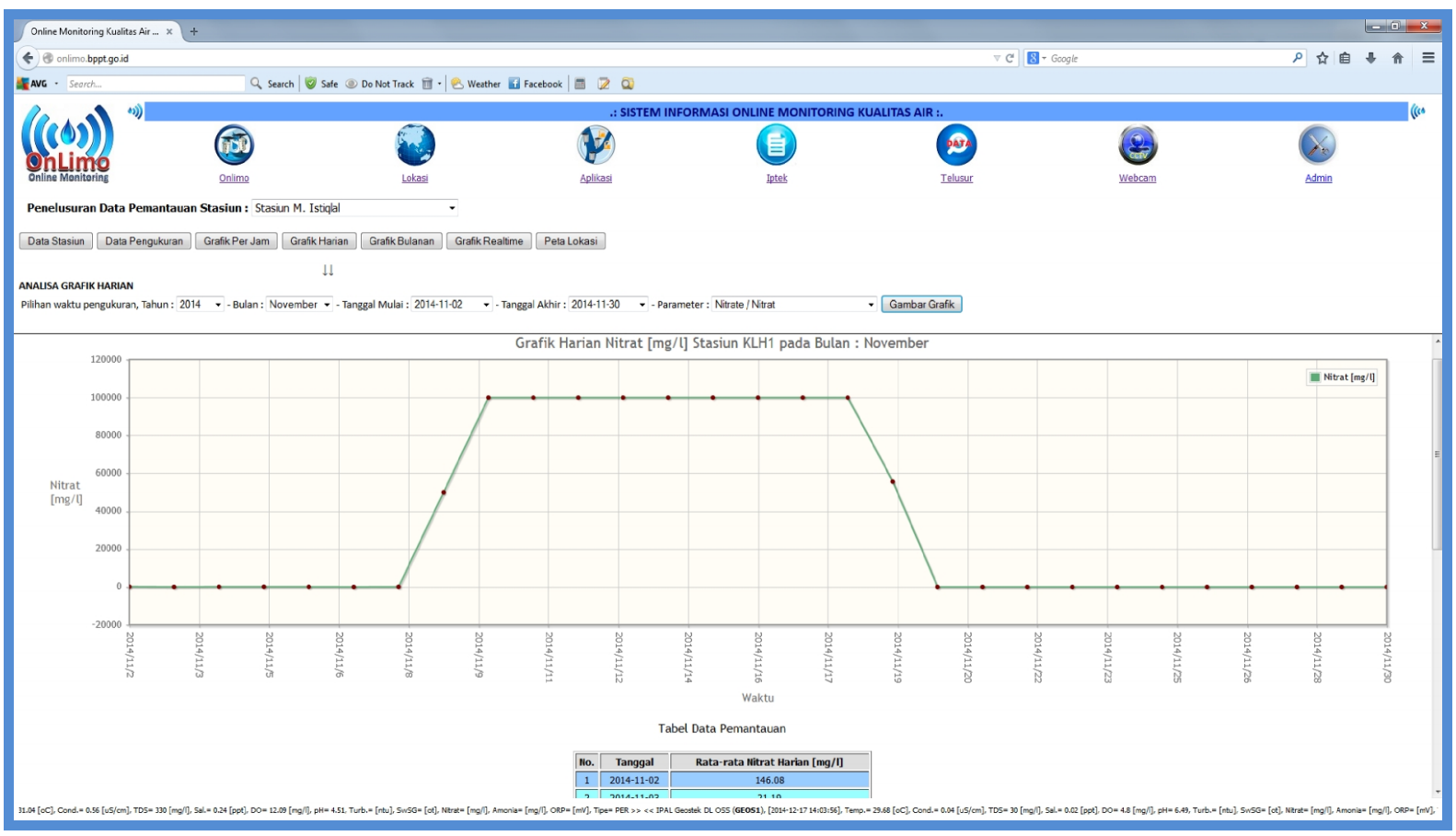

Gambar 21 : Grafik Rata-Rata Harian 2 30 Nov. 2014 Parameter Nitrat. 


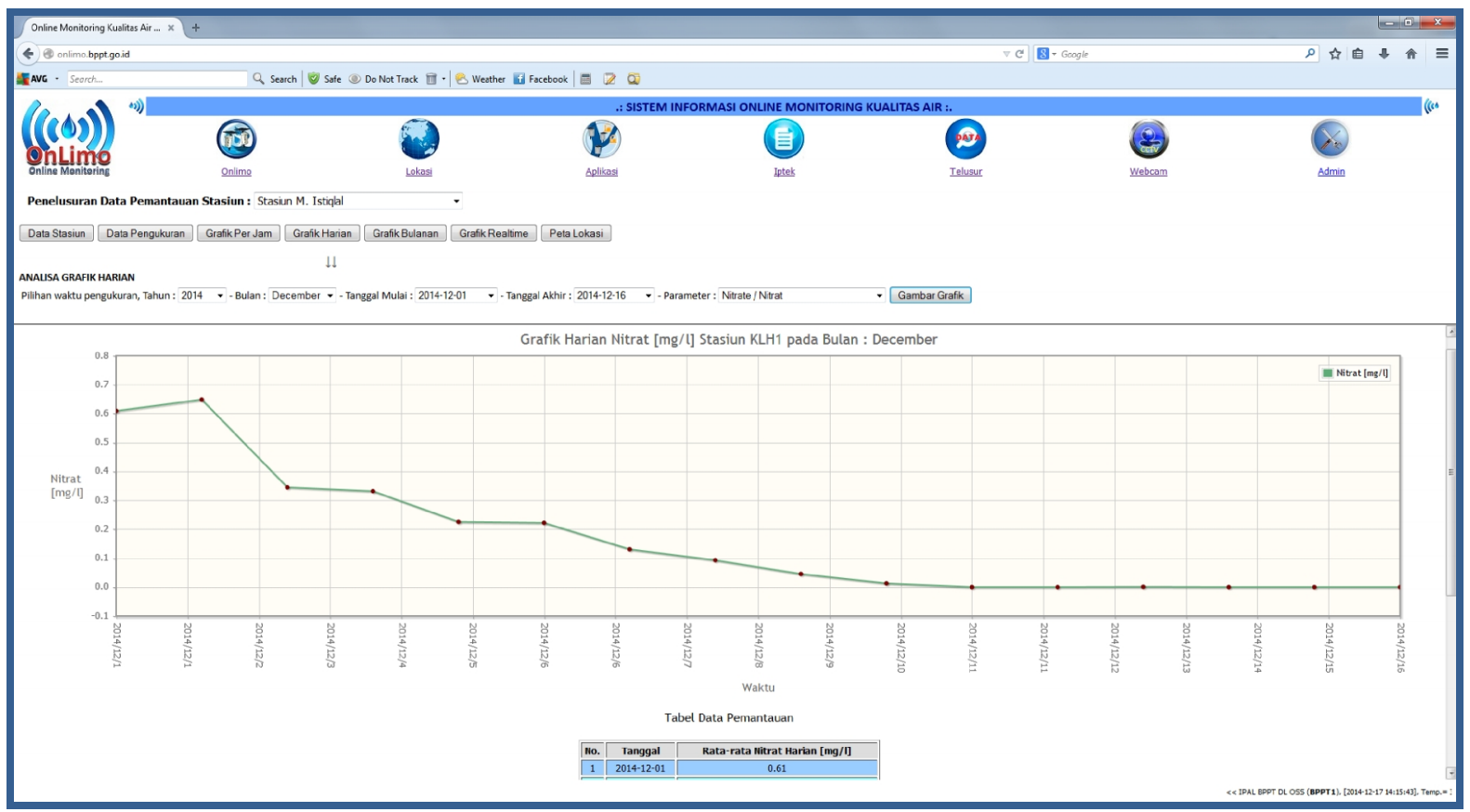

Gambar 22 : Grafik Rata-Rata Harian 1 16 Des. 2014 Parameter Nitrat.

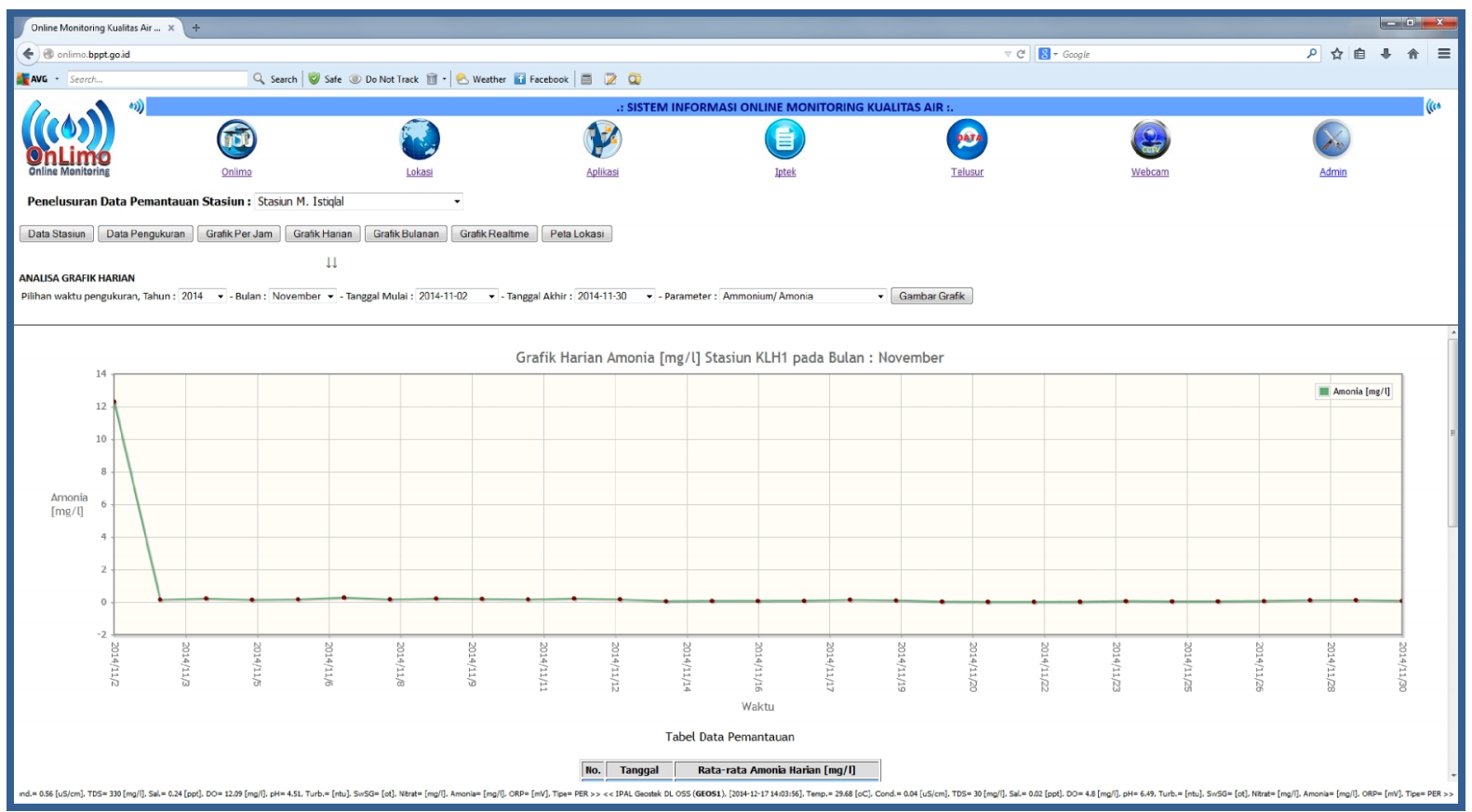

Gambar 23 : Grafik Rata-Rata Harian 2 30 Nov. 2014 Parameter Amonia. 


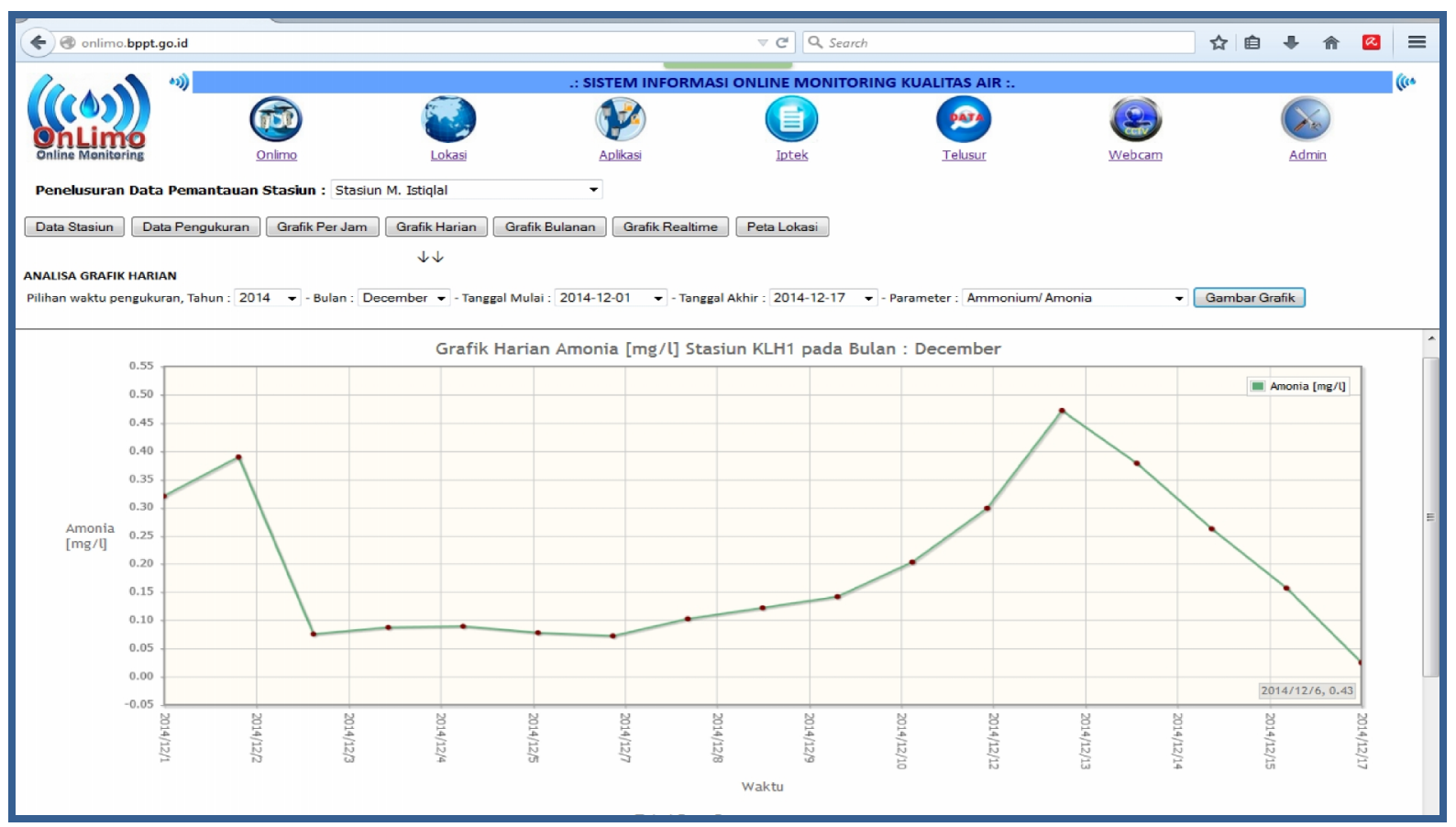

Gambar 24 : Grafik Rata-Rata Harian 1 16 Des. 2014 Parameter Amonia. 